\title{
Bioefficacy of Trichoderma spp. against Bipolaris sorokiniana Causing Spot Blotch Disease of Wheat and Barley
}

\author{
Divya Singh", S.K. Pande, Kavita, Jay Kumar Yadav and Sandeep Kumar \\ Department of Plant Pathology, Narendra Deva University of Agriculture and Technology \\ Faizabad, Uttar Pradesh (224229), India \\ *Corresponding author
}

\begin{tabular}{|c|}
\hline \\
\hline $\begin{array}{l}\text { Bipolaris sorokiniana, } \\
\text { Biological control, } \\
\text { Trichoderma, Mycelial } \\
\text { Growth, Plant height and } \\
\text { Disease severity }\end{array}$ \\
\hline Article Info \\
\hline $\begin{array}{l}\text { Accepted: } \\
\text { 20 February } 2018 \\
\text { Available Online: } \\
10 \text { March } 2018\end{array}$ \\
\hline
\end{tabular}

\section{A B S T R A C T}

Spot blotch caused by Bipolaris sorokiniana (Sacc. in Sorok.) Shoem. is an important disease of Wheat and Barley. The biological control has been proved useful and economical in the control of spot blotch because of the harmful effect of fungicides to human and environment. The Trichoderma viride, Trichoderma harzianum and Trichoderma virens were used in dual culture method to see their effect on mycelial growth of Bipolaris sorokiniana. The inhibition varied among Trichoderma spp. was ranged from 60.76 to $73.07 \%$. The bioagent Trichoderma viride exhibited maximum inhibition percentage $(73.07 \%, 72.30 \%)$ on mycelial growth of Bipolaris sorokiniana. The seed and soil treatment with Trichoderma viride increased plant height, fresh and dry weight of shoot and root as compared to control. Soil treatment with Trichoderma viride (bio agent) was found best with minimum disease severity $(21.51 \%)$ and minimum percent root infection $(10.00 \%)$.

\section{Introduction}

The Wheat and Barley crop both have high nutritional value are cultivated for human consumption all over the world. In India wheat is second important staple food crop after rice whereas Barley was considered as poor man's crop because of its low input requirement and better adaptability to harsh environments, like drought, salinity, alkalinity and marginal lands. The most important uses of Barley in India are as grain feed to livestock and poultry, malt for manufacture of beer and other liquor like whisky, brandy etc. The Spot blotch caused by Bipolaris sorokiniana (Sacc. in Sorok.) Shoem. is a serious disease of Wheat and Barley. In last two decades spot blotch has emerged as serious concern for Wheat and Barley growers in developing world. Bipolaris sorokiniana causes several diseases in its hosts worldwide. It produces broad range of symptoms such as root rot, leaf blotch and black point of seed. The high temperature and high relative humidity 
favours the outbreak of the disease particularly in South Asia s intensive irrigated rice - wheat production systems (Aggrawal et al., 2000) and causes severe yield losses to Wheat crop in South East Asia (Saari, 1998) and marked reduction in grain yield and quality of Barley crop (Nutter et al., 1985; Arabi and Jawahar, 2003). Annual yield loss of Wheat due to this disease in south Asia is estimated at 15-20\% (Duvieller and Sharma, 2009). Yield losses of $25-45 \%$ in Barley crop have been reported in Kazakhstan and $41 \%$ in Russia (Iftikhar et al., 2009). Spot blotch symptoms are characterized by formation of light brown to dark brown coloured elongated oval blotches surrounded by yellow halo. Wheat and Barley crop in eastern Uttar Pradesh, suffers from a number of fungal diseases such as loose smut, black rust, brown rust, yellow rust, covered smut, powdery mildew, stripe disease and net blotch etc. but spot blotch caused by Bipolaris sorokiniana is more severe than other diseases. Spot blotch can be controlled by a number of ways but integrated disease management is the best method for controlling the pathogen (Mehta, 1993; Dubin and Duvieller 2000). Biological control has also proved useful and economical in the control of spot blotch because of the harmful effect of fungicides to human and environment. Trichoderma spp. were used as a potential biological agent for control of foliar blight caused by Bipolaris sorokiniana. Jacobsen et al., (2004) pointed out that biological control should be most effective when used in combination with disease resistance in an integrated disease management system. So, the present research work was carried to evaluate the potential of Trichoderma species for management of Bipolaris sorokiniana.

\section{Materials and Methods}

Isolation: In order to isolate the test pathogen (Bipolaris sorokiniana), infected leaves of barley and wheat showing characteristic blight symptoms were collected from Student
Instructional Farm and Main Experimental Station, Narendra Deva University of Agriculture and Technology, Faizabad. The selected leaves were washed with fresh sterilized water in order to remove the dust particles and surface contaminants. The washed diseased leaves were cut into small bits. The cut leaf pieces were surface sterilized with 0.1 per cent Mercuric Chloride solution and washed thoroughly 3 to 4 times with sterilized water to remove the traces of Mercuric Chloride. The pieces were transferred in Petri dishes containing Potato Dextrose Agar and incubated at $25+2^{0} \mathrm{C}$ for 6 days.

\section{Dual culture technique}

To determine the effect of Trichoderma spp. on mycelial growth of Bipolaris sorokiniana, a dual culture method was used (Fokkema, 1973). The dual culture of three Trichoderma spp. and targeted pathogen were studied on Potato dextrose agar (PDA). $20 \mathrm{ml}$ of PDA medium was poured in plates $(9 \mathrm{~cm})$ and was allowed to solidify.

The discs (5mm diameter) of mycelium cut from the margin of 6 days old culture of each Trichoderma spp. were placed at the edge of each plate, $10 \mathrm{~mm}$ from the periphery then disc of $5 \mathrm{~mm}$ diameter of mycelium cut from the growing edge of 7 days old cultures of Bipolaris sorokiniana were placed on each plate, opposite to the mycelial discs of Trichoderma spp. where as in control plates, two mycelial disc of Bipolaris sorokiniana were placed at the edges of each plate, opposite to each other in complete aseptic condition. All the plates were incubated at $25+2^{\circ} \mathrm{C}$ for about 7 days after inoculation and four replications were maintained for each treatment.

The radial growth of Bipolaris sorokiniana was recorded, compared with control and percentage of growth inhibition was calculated 
by following the formula suggested by Sunder et al., (1995).

$\%$ Inhibition $=\frac{\mathrm{X}-\mathrm{Y}}{\mathrm{X}} \mathrm{X} 100$

Where $\mathrm{X}=$ Radial growth of pathogen alone (control) $\mathrm{Y}=$ Radial growth of pathogen along with antagonist.

Soil Treatment: The inoculum of Bipolaris sorokiniana and Trichoderma viride was grown on sterilized sorghum seeds as described by Joshi et al., (1969). Sorghum seeds were soaked for $24 \mathrm{~h}$ and then transferred to conical flask of $250 \mathrm{ml}$ capacity. The material was sterilized twice on subsequent days at 15 pound pressure for an hour. Bipolaris sorokiniana and Trichoderma viride were grown separately on Potato Dextrose Agar (PDA) and when they were grown bits of culture about $5 \times 2 \mathrm{~cm}$ in size were added to each flask containing autoclaved sorghum seeds and incubated at $25^{\circ} \mathrm{C}$ with periodical shaking to avoid cake formation. The infested seeds were mixed with soil @ 50g/ kg of soil and placed in pots in net house.

Seed Treatment: Barley seeds were treated with conidial suspension of Trichoderma viride. Conidia were harvested from the infested sorghum seeds and washed several time in sterile distilled water. Seed surface was disinfected by soaking in $0.5 \%$ sodium hypochlorite for $3 \mathrm{~min}$ then rinsed three times in sterile distilled water. The seeds were soaked for one hour in Trichoderma spore suspension and air dried. Trichoderma inoculated seed were sown in pots. Sowing was done on 12 December, 2015. Pots are watered at every three days of interval. Four plants were maintained in each pot. After 45 days of planting, disease severity, plant height, percent root infection, fresh and dry weight of shoot and root were recorded. All the treatments are arranged in CRD and data were statistically analyzed.

\section{Results and Discussion}

The effect of Trichoderma isolates i.e. Trichoderma viride, Trichoderma virens and Trichoderma harzianum were evaluated against mycelial growth of Bipolaris sorokiniana of Wheat and Barley by dual culture method (Table 1). The result showed that all isolates of Trichoderma inhibited the growth of Bipolaris sorokiniana and inhibition varied from $60.76-73.07 \%$. The maximum inhibition of mycelial growth of Bipolaris sorokiniana of Wheat and Barley was recorded with Trichoderma viride $(73.07 \%$, $72.30 \%)$ followed by Trichoderma virens (69.22\%, 66.15\%). Minimum inhibition of mycelial growth of Bipolaris sorokiniana of wheat and barley was recorded with Trichoderma harzianum $(63.84 \%, 60.7 \%)$.

The Trichoderma viride exhibited maximum inhibition percentage to mycelial growth of Bipolaris sorokiniana was selected for treatment of seed and soil to evaluate its effect on survival of Bipolaris sorokiniana causing spot blotch disease in Barley and Wheat.

A perusal of data presented in table 2 indicated that all the treatments were significantly superior to control, minimum disease severity $(21.51 \%)$ was recorded with untreated seed +Trichoderma viride treated soil followed by $26.38 \%$ with Trichoderma viride treated seed + infected soil and maximum disease severity $(55.55 \%)$ was noted in control. The minimum percent root infection $(10.00 \%)$ was recorded with untreated seed + Trichoderma viride treated soil followed by $12.90 \%$ with untreated seed + sterilized soil and $22.18 \%$ with $T$. viride treated seed+infected soil. The maximum root infection $(63.25 \%)$ was noted in control. 
Table.1 Effect of Trichoderma spp. on mycelial growth of Bipolaris sorokiniana

\begin{tabular}{|c|c|c|c|}
\hline \multirow{2}{*}{$\begin{array}{c}\text { S. } \\
\text { No. }\end{array}$} & \multirow[t]{2}{*}{ Treatment } & \multicolumn{2}{|c|}{ Dual culture } \\
\hline & & $\begin{array}{c}\text { Radial } \\
\text { growth }(\mathrm{cm})\end{array}$ & $\begin{array}{c}\text { Percent } \\
\text { inhibition }\end{array}$ \\
\hline $\mathbf{T}_{1}$ & T. viride $\mathrm{x}$ B. sorokiniana (wheat) & 0.87 & $\begin{array}{l}73.07 \\
(58.81)\end{array}$ \\
\hline $\mathbf{T}_{2}$ & T. harzianum x B. sorokiniana (wheat) & 1.07 & $\begin{array}{c}63.84 \\
(53.04)\end{array}$ \\
\hline $\mathbf{T}_{3}$ & T. virens $\mathrm{x}$ B. sorokiniana (wheat) & 1.00 & $\begin{array}{c}69.22 \\
(56.33)\end{array}$ \\
\hline $\mathbf{T}_{4}$ & T. viride $\mathrm{x}$ B. sorokiniana (barley) & 0.90 & $\begin{array}{c}72.30 \\
(58.33)\end{array}$ \\
\hline $\mathbf{T}_{5}$ & T. harzianum x B. sorokiniana (barley) & 1.27 & $\begin{array}{c}60.76 \\
(51.23)\end{array}$ \\
\hline $\mathbf{T}_{6}$ & T. virens $\mathrm{x}$ B. sorokiniana (barley) & 1.10 & $\begin{array}{c}66.15 \\
(54.43)\end{array}$ \\
\hline $\mathbf{T}_{7}$ & B. sorokiniana (wheat) & 3.25 & ---- \\
\hline $\mathbf{T}_{8}$ & B. sorokiniana (barley) & 3.25 & ---- \\
\hline & CD at5\% & 0.17 & 3.88 \\
\hline
\end{tabular}

*Figures given in parenthesis are transformed value

*All the values are average of four replications

Table.2 Effect of Trichoderma seed and soil treatment on survival of Bipolaris sorokiniana

\begin{tabular}{|c|c|c|c|c|c|c|c|}
\hline Treatments & $\begin{array}{l}\text { Disease } \\
\text { severity } \\
(\%)\end{array}$ & $\begin{array}{l}\% \text { Root } \\
\text { infected }\end{array}$ & $\begin{array}{l}\text { Plant } \\
\text { height } \\
(\mathrm{cm})\end{array}$ & $\begin{array}{l}\text { Fresh } \\
\text { weight } \\
\text { of } \\
\text { shoot } \\
\text { (g) }\end{array}$ & $\begin{array}{l}\text { Dry } \\
\text { weight } \\
\text { of } \\
\text { shoot } \\
\text { (g) }\end{array}$ & $\begin{array}{l}\text { Fresh } \\
\text { weight } \\
\text { of } \\
\text { root } \\
\text { (g) }\end{array}$ & $\begin{array}{l}\text { Dry } \\
\text { weight } \\
\text { of } \\
\text { root } \\
\text { (g) }\end{array}$ \\
\hline $\begin{array}{l}\text { T. viride treated seed }+B \text {. } \\
\text { sorokiniana infected soil }\end{array}$ & $\begin{array}{c}33.30 \\
(35.07)\end{array}$ & $\begin{array}{c}27.50 \\
(31.60)\end{array}$ & 36.50 & 6.40 & 1.84 & 0.48 & 0.056 \\
\hline $\begin{array}{l}\text { T. viride treated seed+ } \\
\text { infected soil }\end{array}$ & $\begin{array}{c}26.38 \\
(30.82)\end{array}$ & $\begin{array}{c}22.18 \\
(28.07)\end{array}$ & 37.43 & 6.66 & 1.96 & 0.56 & 0.062 \\
\hline $\begin{array}{l}\text { Untreated seed }+T \text {. viride } \\
\text { treated soil }\end{array}$ & $\begin{array}{c}21.51 \\
(27.54)\end{array}$ & $\begin{array}{c}10.00 \\
(18.21)\end{array}$ & 39.81 & 8.25 & 2.44 & 0.70 & 0.07 \\
\hline $\begin{array}{l}\text { Untreated seed + sterilized } \\
\text { soil }\end{array}$ & $\begin{array}{c}28.46 \\
(31.98)\end{array}$ & $\begin{array}{c}12.90 \\
(20.62)\end{array}$ & 35.00 & 5.40 & 1.70 & 0.36 & 0.05 \\
\hline $\begin{array}{l}\text { Untreated seed+ } B \text {. } \\
\text { sorokiniana infected soil } \\
\text { (control) }\end{array}$ & $\begin{array}{c}55.55 \\
(48.19)\end{array}$ & $\begin{array}{c}63.25 \\
(52.63)\end{array}$ & 31.09 & 4.21 & 1.54 & 0.26 & 0.031 \\
\hline CD at $5 \%$ & 6.88 & 4.52 & 4.3 & 1.37 & 0.49 & 0.16 & 0.02 \\
\hline
\end{tabular}

*Wt. -Weight

*Figures given in parenthesis are transformed value

*All the values are average of four replications 
Plant growth characters like plant height, fresh and dry weight of shoot and root were higher in all treatment compared to control. The maximum plant height $(39.81 \mathrm{~cm})$, fresh weight of shoot $(8.25 \mathrm{~g})$ and root $(0.70 \mathrm{~g})$ and dry weight of shoot $(2.44 \mathrm{~g})$ and root $(0.07 \mathrm{~g})$ were recorded with untreated seed + Trichoderma viride treated soil.

The minimum plant height $(31.09 \mathrm{~cm})$ fresh weight of shoot $(4.21 \mathrm{~g})$ and root $(0.26 \mathrm{~g})$ and dry weight of shoot $(1.54 \mathrm{~g})$ and root $(0.031 \mathrm{~g})$ were recorded with control. The present findings are in agreement with the finding of Salehpour et al., (2005) who reported that reduction in the growth of Bipolaris sorokiniana mycelia was highest with Trichoderma viride and also found that seed soaking and soil treatments with Trichoderma viride T112 and MO were the most effective in the reduction of infection caused by Bipolaris sorokiniana compared with the control ( $\mathrm{p}<0.01)$, all isolates of Trichoderma increased plant height and fresh and dry weight of roots and shoots of wheat seedlings compared with the control. Kumar et al., (2009) tested efficacy of Trichoderma viride, Trichoderma harzianum and Trichoderma virens against Helminthosporium maydis, in which Trichoderma viride inhibited the radial growth of Helminthosporium maydis to an extent of $60.7 \%$ followed by Trichoderma harzianum $(55.1 \%)$ and Trichoderma virens $(52.6 \%)$ and his studies on hyphal interaction between antagonists and test fungus revealed disorganization of protoplasmic content and lysis of host hyphae. The soil application of bioagents was more effective in protecting the crop than foliar spray. The seed and soil treatment with Trichoderma spp. alone increased plant height, fresh and dry weight of shoot and root compared with control. It is in accordance with result showing that some fungal isolates and bacterial strains are capable of promoting plant growth (El Abyad., 1992; Jones., 1996).
Among three Trichoderma spp. Trichoderma viride exhibited maximum inhibition percentage to mycelial growth of Bipolaris sorokiniana of Wheat and Barley. Soil treatment with Trichoderma viride (bio agent) effectively inhibits the growth of Bipolaris sorokiniana causing spot blotch of wheat and barley in turn protecting the losses of the crop. Wheat and Barley crops are cultivated for human consumption therefore manage the disease using bio agent instead of using chemical fungicide will protect the consumers from the ill effects of chemical fungicides.

\section{References}

Aggarwal, P. K., K. K. Talukdar and R. K. Mall. 2000. Potential yields of RiceWheat system in the Indo- Gangetic Plains of India. Consortium paper series10. Rice-wheat consortium for the Indo-Gangetic Plains, New Delhi, India 16

Arabi, M. I. E. and M. Jawahar. 2003. Pathotypes of Cochliobolus sativus (spot blotch) on Barley in Syria. Journal of Plant pathology 85:193- 196

Dubin, H. J. and E. Duveiller. 2000. Helminthosporium leaf blights of wheat: integrated control and prospects for the future. In: proc. Int. conf. integrated Plant Disease Management for Sustainable Agriculture, New Delhi, 1015 Nov. 1997, vol. (1), pp 575-579

Duveiller, E. M. and R.C. Sharma. 2009. Genetic improvement and crop management strategies to minimize yield losses in warm non-traditional Wheat growing areas due to Spot blotch pathogen Cochliobolus sativus. Journal of Phytopathology 157:521-534.

El-Abyad, M. S. and N. H. El-Batanouny. 1992. Inhibitory effect of UV mutant of Streptomyces corchrusi and Streptomyces spiroverticillatus on bean 
and banana with pathogen. Canadian Journal of Botany 71: 1080-1086.

Fokkema, N J. 1973. The role of saprophytic fungi in antagonism against Drechslera sorokiniana (Helminthosporium sativum) on agar plate and on rye leaves with pollen physiol. Plant Pathology 195-205.

Iftikhar, S., S. Asad, A u R. Rattu, M. Fayyaz and A. Munir. 2009. Selection of Barley germplasm resistant to spot blotch. Pakistan Journal of Botany 41:309-314.

Jacobsen, B. J., N. K. Zidack and B. J. Larson. 2004. The role of Bacillusbased biological control agents in integrated pest management systems: Plant diseases. Phytopathology 94: 1272-1275.

Jones, C. R. and D. A. Samac. 1996. Biological control of fungi causing alfalfa seedling damping off with a disease suppresive strain of Streptomyces. Biological Control 7: 196-204

Joshi, L. M., L. B. Goel and B. L. Renfro. 1969. Multiplication of inoculum of Helminthosporium turcicum on sorghum seed. Indian Phytopathology 22: 146-148.

Kumar, S., A. Rani and M. M. Jha. 2009. Potential of Trichoderma spp. as biocontrol agents against pathogens causing maydis leaf blight of maize. Journal of Biological Control 23(1): 8991.
Mathur, A. K. and G. C. Bhatnagar. 1991. Barley stripe: Its prevalence and loss in grain yield. Indian Journal of Mycology and Plant Pathology 21: 280-282.

Mehta, Y. R. 1993. Spot blotch (Bipolaris sorokiniana). In: Mathur S B and Cunfer B M (eds), Seed borne disease and seed health testing of wheat. Institute of seed pathology for developing countries, Copenhagen, Denmark, 105-112.

Nutter, F. W., V. D. Jr Pederson and A. E. Foster. 1995. Effect of inoculation with Cochliobolus sativus at specific growth stages on grain yield and quality of malting barley. Crop Sciences 2: 993938

Saari, E. E. 1998 Leaf blight diseases and associated soil borne fungal pathogens of Wheat in north and south East Asia. In: Duveiller, Dubin H J, Reeves J and Mcnab A. (eds), Helminthosoprium Diseases of Wheat: Spot Blotch and Tan Spot. CIMMYT, Mexico 37-51.

Salehpour, M., H. R. Etebarian, A. Roustaei, G. Khodakaramian and H. Aminian. 2005. Biological control of common root rot of wheat (Bipolaris sorokiniana) by Trichoderma isolates. Plant Pathology Journal 4(1): 85-90.

Sundar, A. R., N. D. Das and D. Krishnaveni. 1995. In-vitro Antagonism of Trichoderma spp. against two Fungal Pathogens of Castor. Indian Journal of Plant Pathology 23(2): 152-155.

\section{How to cite this article:}

Divya Singh, S.K. Pande, Kavita, Jay Kumar Yadav and Sandeep Kumar. 2018. Bioefficacy of Trichoderma spp. against Bipolaris sorokiniana Causing Spot Blotch Disease of Wheat and Barley. Int.J.Curr.Microbiol.App.Sci. 7(03): 2322-2327. doi: https://doi.org/10.20546/ijcmas.2018.703.272 